\title{
What is MySQL, History and Functions
}

\author{
CHARZON \\ 165100040
}

Fakultas Komputer, 448757249

Charzon.student@umitra.ac.id

What is MySQL - MySQL is a database management system (English: database management system) or a multi-purpose, multi-user DBMS, with around 6 million installations worldwide. MySQL AB makes MySQL available as free software under the GNU General Public License (GPL), but they also sell under commercial licenses for cases where its use does not match the use of GPL.

You can think of a MySQL database as a container that stores strings (text based) data. Images, media, files, audio files, and things that are truly natural do not have to be stored in the database. The trick is to put the file file on the server in the folder and only reference the name and path in the database

Keywords: What is MySQL, History and Functions 


\section{A. INTRODUCTION}

What is MySQL - MySQL is a database management system or a multi-purpose, multi-user DBMS, with around 6 million installations worldwide. MySQL AB makes MySQL available as free software under the GNU General Public License (GPL), but they also sell under commercial licenses for cases where its use does not match the use of GPL.

Unlike projects such as Apache, where software is developed by the general community, and the copyright for the source code is owned by their respective authors, MySQL is owned and sponsored by a Swedish commercial company MySQL $\mathrm{AB}$, which holds the copyright almost to all the source code. The two Swedes and one Finnish who founded MySQL AB are: David Axmark, Allan Larsson, and Michael "Monty" Widenius.

\section{Origin of the MySQL Name}

The origin of naming MySQL itself is rather unique. Monty said:
"It is not perfectly clear where the name MySQL derives from. The TCX base directory and a large amount of their libraries and tools have the prefix 'My' for well over ten years. However, my daughter (some years younger) is also named My. So which of the two names to MySQL is still a mystery. "

Various sources stated, even on the MySQL site itself that "My" from MySQL came from the name of Monty's daughter. But like the quote above, Monty also admitted that as long as he was in TcX, the library and applications developed by the company also started with the prefix "My"

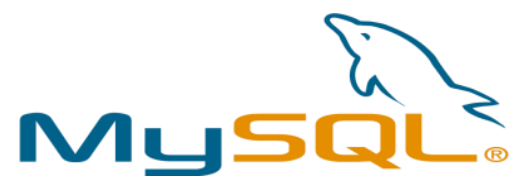

The dolphin logo in the MySQL symbol is called Sakila, which comes from a "Name the Doplhin" contest held by MySQL AB. This Sakila name was submitted by Ambrose Twebaze, an open source programmer from Swaziland, Africa. 'Sakila' has roots from Siswati, the language used in Swaziland. 


\section{MySQL function}

MySQL has various functions, namely

You can think of a MySQL database as a container that stores strings (text based) data. Images, media, files, audio files, and things that are truly natural do not have to be stored in the database. The trick is to put the file file on the server in the folder and only reference the name and path in the database.

Here are some types of PHP and MySQL applications that can help you make:

- Blog Site

- Custom Database Dynamic Website Driver (such as developPHP)

- E-commerce and Custom Online Shop Programming

- Social Network and community

- Guestbook

- All Dynamic Websites

- Client and Customer information.

MySQL stands for

MySQL stands for "My Structured Query Language". This program runs as a server providing multi-user access to a number of databases.
Advantages of MySQL

- Is one portable software

- MySQL is one of the opensource DBMS

- Multi-User

- Has a variety of data types

- Has good security features

- Complete administrative tools

- More flexible table structure

- Can be integrated with various programming languages

- Does not require high hardware specifications

- Small RAM can use it

\section{Lack of MySQL}

- It is difficult to apply to agencies or companies with large databases

- Poor support

- Not popular for game and mobile applications

\section{B. CONCLUSION}

MySQL is a multi-level, multiuser and SQL database management system software MySQL is also useful as a container that stores strings (text based) data. Images, media, files, audio files, and things that are truly natural do not have to be stored in the database. The trick is to put the file file on the server in the 
folder and only reference the name and path in the database

C. ACKNOWLEDGEMENT University Of Indonesia University Of Mitra Indonesia Telkom University University Of Mellbourne Saitama University

\section{REFERENCE (Based APA)}

\begin{tabular}{|c|c|}
\hline $\begin{array}{l}\text { A. S. Putra } A \\
\text { "Knowledge }\end{array}$ & $\begin{array}{l}\text { nd O. M. Febriani, } \\
\text { Management }\end{array}$ \\
\hline Online App & lication In Pdam \\
\hline Lampung & Province," \\
\hline Prosiding & International \\
\hline Conference & On Information \\
\hline $\begin{array}{l}\text { Technology } \\
\text { (Icitb). } 2018\end{array}$ & $\begin{array}{l}\text { And Business } \\
\text { Pp. 181-187. }\end{array}$ \\
\hline
\end{tabular}

[2] A. S. Putra, O. M. Febriani, And B. Bachry, "Implementasi Genetic Fuzzy System Untuk Mengidentifikasi Hasil Curian Kendaraan Bermotor Di Polda Lampung," J. Sist. Inf. Dan Manaj. Basis Data, Vol. 1, No. 1, Pp. 21-30, 2018.

[3] O. M. Febriani And A. S. Putra, "Sistem Informasi Monitoring Inventori Barang Pada Balai Riset Standardisasi Industri Bandar Lampung," J. Inform., Vol. 13, No. 1, Pp. 90-98, 2014.

[4] Putra, Arie Setya. "2018 Artikel Struktur Data, Audit Dan Jaringan Komputer." (2018).

[5] Putra, A. S. (2018, July 17). Paperplain Fundamental Create Application With Borland Delphi 7.0 University Of Mitra Indonesia. Retrieved From
Osf.Io/Pbrn9.

\section{E. REFERENCE (Based APA)}

Putra, A. S., Aryanti, D. R., \& Hartati, I. (2018, November). Metode SAW (Simple Additive Weighting) sebagai Sistem Pendukung Keputusan Guru Berprestasi (Studi Kasus: SMK Global Surya). In Prosiding Seminar Nasional Darmajaya (Vol. 1, No. 1, pp. 85-97).

Sari, D. P., Febriani, O. M., \& Putra, A. S. (2018, November). Perancangan Sistem Informasi SDM Berprestasi pada SD Global Surya. In Prosiding Seminar Nasional Darmajaya (Vol. 1, No. 1, pp. 289-294).

Putra, A. S. (2018). Paperplain: Execution Fundamental Create Application With Borland Delphi 7.0 University Of Mitra Indonesia.

Putra, A. S., Sukri, H., \& Zuhri, K. Sistem Monitoring Realtime Jaringan Irigasi Desa (JIDES) Dengan Konsep Jaringan Sensor Nirkabel. IJEIS (Indonesian Journal of Electronics and Instrumentation Systems), 8(2), 221232.

Darmawan, A., Yuliawati, D., Marcella, O., \& Firmandala, R. (2016). Sistem Absensi dan Pelaporan Berbasis Fingerprint dan SMS Gateway. EXPLORE, 7(1).

Febriani, O. M., Wahyuni, T., \& Yusuf, S. (2017). DESIGN OF WEBSITE-BASED INFORMATION SYSTEM FOR EDOCUMENT ADMINISTRASI IN THE 
COMMUNITY SERVICE UNIT (A Case Study at Rajabasa District). INTERNATIONAL JOURNAL OF COMPUTERS \& TECHNOLOGY, 16(7), 7010-7020.

Febriani, O. M., \& Wahyuni, T. (2017, October). PERANCANGAN SISTEM E-DOCUMENT ADMINISTRASI LOGBOOK PENELITIAN PADA UNIT LAYANAN DI BANDAR LAMPUNG. In Prosiding Seminar Nasional Darmajaya (Vol. 1, No. 1, pp. 187-194).

Febriani, O. M., \& Permadi, A. B. (2017). Implementasi Sistem Aplikasi Data Bimbingan dan Pelanggaran Siswa pada Sekolah Menengah Atas di Lampung Tengah dengan Metode Analisis dan Desain Sistem Terdistribusi (SSAD). EXPERT, 7(1).

Febriani, O. M., \& Ambarwati, L. (2015). PERANCANGAN APLIKASI PENGOLAHAN DATA PENJUALAN UKM KELANTING KHAS TELO DESA SIDOHARJO KECAMATAN JATI AGUNG KABUPATEN LAMPUNG SELATAN. Jurnal Teknologi Informasi dan Bisnis Pengabdian Masyarakat Darmajaya, 1(1), 77-95.

Febriani, O. M. (2015). Rancang Bangun Aplikasi Ecommercemenggunakan Freewebstore pada UKM Kelanting di Desa Sidoharjo Lampung Selatan. Prosiding Sembistek 2014, 1(02), 446-458. 